\title{
Adult onset Still's disease: clinical experience with 18 patients over 15 years in northern India*
}

\author{
P Bambery, R J Thomas, H S Malhotra, Upjeet Kaur, S R Bhusnurmath, S D Deodhar
}

\begin{abstract}
Over a 15 year period 18 patients (eight men, 10 women), 16-50 years old, were diagnosed as having adult onset Still's disease. Fever and arthralgia were always present but prominent lymphadenopathy was uncommon and the serosa were rarely affected. The typical rash of this disease was observed in nine patients. Several complications, including deforming arthritis, amyloidosis, granulomatous hepatitis, uveitis, scleritis, cutaneous vasculitis, and cardiomyopathy, were observed during follow up. Two patients were affected by a nosocomial infection during immunosuppressive treatment for uncontrolled disease. There were no characteristic features at necropsy. Ten patients had a monocyclic course that responded well to aspirin and indomethacin, whereas eight had a polycyclic pattern which invariably required treatment with corticosteroids. Serious complications developed exclusively in the latter group. This group of patients requires early, intensive disease modifying treatment.
\end{abstract}

The systemic disorder indicating the onset of a form of juvenile arthritis was called Still's disease in recognition of the original observations made nearly a century ago. ${ }^{1}$ Almost all the salient clinical features of this condition were described in $1897^{2}$ and only the typical rash was added later. ${ }^{3}$ Although a similar syndrome was subsequently noted to affect adults, it was not called adult onset Still's disease until 1971. ${ }^{4}$ High fever, joint pain, skin rash, serositis, hepatosplenomegaly, and lymphadenopathy are the characteristic clinical features of this rare disease, for which there is no diagnostic test. ${ }^{5}$

Until 1988 less than 300 patients had been described. ${ }^{5-7}$ This disease is, however, probably more common than this number suggests. ${ }^{58}$ It was initially considered to be a relatively benign condition, ${ }^{9}$ but serious complications, morbidity, and mortality have now been recognised. ${ }^{10} 11$ Our experience with 18 patients over 15 years is the basis of this paper. Six of these patients were described previously. ${ }^{12}$

\section{Patients and methods}

All patients were seen and treated by the rheumatology clinic at the Nehru Hospital attached to the Postgraduate Institute of Medical Education and Research, Chandigarh between January 1975 and December 1989. Almost all

${ }^{*}$ Presented in abstract form at the annual conference of the Indian Rheumatism Association, Chandigarh, 1989. these patients were admitted for the initial evaluation of a febrile illness. Subsequent admissions were for specific complications. Since 1983, one of us (PB) has maintained a detailed prospective record of all patients diagnosed to have adult onset Still's disease. A retrospective analysis of clinic and admission files and unit records was undertaken for the period 1975-82.

After a detailed history and physical examination, all patients underwent a series of tests to establish the cause of the fever. These included: complete blood counts; biochemical tests of renal and hepatic function; appropriate microbiological tests on blood, urine, stools, sputum, throat swabs, and other body fluids; serological tests for typhoid, brucellosis, hepatitis B, malaria, visceral leishmaniasis, fungal infection, and syphilis; determination of rheumatoid factor by sheep cell agglutination and latex fixation; determination of antinuclear antibodies using rat liver as substrate; and histological examination of liver, bone marrow, lymph nodes, and skin with special stains for acid fast bacilli and fungi. Radiological examination of the chest and the joints was performed for all patients, but abdominal ultrasonography and computed tomography scans have been used regularly for the last five years only. The diagnostic criteria of Medsger and Christy were used throughout this study. ${ }^{11}$

\section{Results}

Eighteen patients fulfilled the proposed diagnostic criteria for adult onset Still's disease. ${ }^{5} 11$ Fourteen were seen during the prospective study (1983-9) and four were identified retrospectively (1975-82). During this period our unit saw approximately 115000 general medical patients at a weekly outpatients clinic, 9000 referred patients at twice weekly rheumatology clinics, and almost 7000 admitted medical patients. Ten of these patients are currently on regular follow up visits, three have died, and the others had been well for one to four years when last seen.

Most of the patients (61\%) were in the second and third decade of life but four $(22 \%)$ were over 40 years of age. The mean duration of fever was 24.4 months (range 1-84 months). Table 1 summarises the clinical and laboratory data of all the patients and table 2 compares these data with those from other large series of patients. None of these patients has developed any other disease during follow up which could explain the febrile illness for which a diagnosis of adult onset Still's disease was made. Table 3 lists
S R Bhusnurmath Dr Bambery.
Dr

Accepted for publication 29 May 1991 
Table 1 Clinical features at presentation of 18 patients with adult onset Still's disease

\begin{tabular}{|c|c|c|c|c|c|c|c|c|c|c|c|}
\hline $\begin{array}{l}\text { Patient } \\
\text { No }\end{array}$ & $\begin{array}{l}\text { Age } \\
\text { (years) }\end{array}$ & Sex & $\begin{array}{l}\text { Duration } \\
\text { of fever } \\
\text { (months) }\end{array}$ & $\begin{array}{l}\text { Foint } \\
\text { pain* }\end{array}$ & Rasht & Serosalf & $\begin{array}{l}\text { Liver } \\
\text { enlargedt }\end{array}$ & $\begin{array}{l}\text { Spleen } \\
\text { enlargedt }\end{array}$ & $\begin{array}{l}\text { Enlargement } \\
\text { of lymph } \\
\text { nodes }\end{array}$ & $\begin{array}{l}\text { Total leucocyte } \\
\text { count } \times 10^{9} / l\end{array}$ & $\begin{array}{l}\text { Erythrocyte } \\
\text { sedimentation } \\
\text { rate } \\
(\mathrm{mm} / \mathrm{h})\end{array}$ \\
\hline $\begin{array}{r}1 \\
2 \\
3 \\
4 \\
5 \\
6 \\
7 \\
8 \\
9 \\
10 \\
11 \\
12 \\
13 \\
14 \\
15 \\
16 \\
17 \\
18\end{array}$ & $\begin{array}{l}17 \\
50 \\
21 \\
21 \\
36 \\
23 \\
18 \\
50 \\
30 \\
20 \\
18 \\
16 \\
23 \\
45 \\
32 \\
38 \\
45 \\
19\end{array}$ & $\begin{array}{l}M \\
F \\
M \\
M \\
F \\
M \\
M \\
F \\
F \\
M \\
M \\
F \\
M \\
F \\
F \\
F \\
F \\
F\end{array}$ & $\begin{array}{r}3 \\
30 \\
3 \\
1 \\
56 \\
2 \\
2 \\
2 \\
2 \\
36 \\
36 \\
36 \\
6 \\
2 \\
84 \\
60 \\
42 \\
36 \\
3\end{array}$ & $\begin{array}{l}\text { POLY } \\
\text { POLY } \\
\text { PAUCI } \\
\text { POLY } \\
\text { POLY } \\
\text { POLY } \\
\text { PAUCI } \\
\text { PAUCI } \\
\text { POLY } \\
\text { POLY } \\
\text { POLY } \\
\text { POLY } \\
\text { POLY } \\
\text { POLY } \\
\text { POLY } \\
\text { POLY } \\
\text { POLY } \\
\text { POLY }\end{array}$ & $\begin{array}{l}- \\
+ \\
- \\
+ \\
- \\
+ \\
- \\
- \\
- \\
- \\
- \\
+ \\
+ \\
+ \\
+ \\
+ \\
+ \\
+\end{array}$ & $\begin{array}{l}\text { PL, PC } \\
- \\
- \\
- \\
\text { PE } \\
- \\
- \\
- \\
- \\
- \\
- \\
- \\
\text { PL } \\
- \\
\text { PL } \\
\text { PE } \\
- \\
-\end{array}$ & $\begin{array}{l}+ \\
+ \\
+ \\
+ \\
+ \\
+ \\
+ \\
+ \\
- \\
+ \\
+ \\
+ \\
+ \\
+ \\
+ \\
+ \\
+ \\
+\end{array}$ & $\begin{array}{l}- \\
+ \\
+ \\
+ \\
- \\
+ \\
+ \\
- \\
+ \\
+ \\
- \\
- \\
- \\
+ \\
+ \\
+ \\
+ \\
-\end{array}$ & $\begin{array}{l}+ \\
+ \\
+ \\
- \\
++ \\
+ \\
+ \\
+ \\
- \\
- \\
+ \\
+ \\
+ \\
+ \\
++ \\
+ \\
+ \\
+\end{array}$ & $\begin{array}{r}27 \cdot 6 \\
13 \cdot 0 \\
18 \cdot 0 \\
15 \cdot 0 \\
6 \cdot 0 \\
16 \cdot 0 \\
20 \cdot 0 \\
14 \cdot 0 \\
7 \cdot 0 \\
9 \cdot 6 \\
12 \cdot 0 \\
\mathrm{NA} \\
13 \cdot 0 \\
12 \cdot 6 \\
9 \cdot 0 \\
16 \cdot 0 \\
15 \cdot 0 \\
12 \cdot 0\end{array}$ & $\begin{array}{l}60 \\
65 \\
62 \\
55 \\
55 \\
50 \\
65 \\
50 \\
80 \\
30 \\
32 \\
\mathrm{NA} \\
30 \\
40 \\
36 \\
60 \\
58 \\
32\end{array}$ \\
\hline
\end{tabular}

POLY = polyarticular; $\mathrm{PAUCI}=$ pauciarticular .

$t-=$ absent; $+=$ present; $++=$ large lymph nodes, suggesting lymphoma

$\ddagger \mathrm{PL}=$ pleural effusion; $\mathrm{PC}=$ pericarditis; $\mathrm{PE}=$ peritoneal fluid.
$\mathrm{M}=$.

$M=$ male; $F=$ female

Table 2 Comparative clinical and laboratory features of large reported series of patients with adult onset Still's diseas

\begin{tabular}{|c|c|c|c|c|}
\hline & \multicolumn{4}{|l|}{ Reference } \\
\hline & Esdaile $^{6}$ et al & Larson $^{5}$ & $\begin{array}{l}\text { Wouters and } \\
\text { Van der Putte }\end{array}$ & This work \\
\hline $\begin{array}{l}\text { No of patients } \\
\text { Sex ratio }(M: F) \\
\text { Age range (years) }\end{array}$ & $\begin{array}{l}58 \\
3: 4 \\
16-35\end{array}$ & $\begin{array}{l}17 \\
10: 7 \\
7-44\end{array}$ & $\begin{array}{l}45 \\
2: 3 \\
16-65\end{array}$ & $\begin{array}{l}18 \\
4: 5 \\
16-50\end{array}$ \\
\hline $\begin{array}{l}\text { Observations (\%)* } \\
\text { Fever } \\
\text { Joint pain } \\
\text { Rash } \\
\text { Serosal inflammation } \\
\text { Lymphadenopathy } \\
\text { Splenomegaly } \\
\text { ESR }>30 \mathrm{~mm} \text { first hour } \\
\text { TLC }>10 \times 10^{10} / 1 \\
\text { Antinuclear factor } \\
\text { Rheumatoid factor }\end{array}$ & $\begin{array}{r}83 \\
98 \\
90 \\
57 \\
48 \\
45 \\
100 \\
97 \\
2 \\
2\end{array}$ & $\begin{array}{r}100 \\
100 \\
84 \\
48 \\
72 \\
48 \\
84 \\
84 \\
\text { NA } \\
\text { NA }\end{array}$ & $\begin{array}{r}84 \\
98 \\
82 \\
53 \\
71 \\
36 \\
100 \\
98 \\
4 \\
4\end{array}$ & $\begin{array}{r}100 \\
100 \\
50 \\
28 \\
67 \\
56 \\
100 \\
76 \\
0 \\
0\end{array}$ \\
\hline
\end{tabular}

${ }^{\mathrm{F}} \mathrm{ESR}=$ erythrocyte sedimentation rate; $\mathrm{TLC}=$ total leucocyte count; NA=not applicable. $\mathrm{M}=$ male; $\mathbf{F}=$ female several complications of adult onset Still's disease which were observed.

\section{ARTICULAR COMPLICATIONS}

Radiological evidence of peripheral joint destruction and ankylosis was present in nine $(50 \%)$ patients at the last evaluation. The proximal joints of four of these patients were also affected. The most common radiological abnormality was in the wrist. Two postmenopausal patients had hip fractures following minor trauma but recovered with conservative management. Five patients currently have no joint problems, five are functional class II, four are functional class III, and one is crippled.

\section{HEPATIC COMPLICATIONS}

An increase in isolated hepatic enzymes was observed in a third of the patients but clinically important liver dysfunction was seen in only two $(11 \%)$. Hepatic granulomas were observed in a middle aged woman ${ }^{12}$ and treatment for tuberculosis was begun. The granulomatous inflammation persisted and progressed in a way similar to chronic active hepatitis. No cause

Table 3 Clinical course, treatment, response, complications, and outcome of 18 patients with adult onset Still's disease

\begin{tabular}{|c|c|c|c|c|c|c|c|}
\hline \multirow{2}{*}{$\begin{array}{l}\text { Patient } \\
\text { No }\end{array}$} & \multicolumn{4}{|c|}{ Treatment } & \multirow[t]{2}{*}{ Courset } & \multirow[t]{2}{*}{ Complications } & \multirow{2}{*}{$\begin{array}{l}\text { Outcome or } \\
\text { functional } \\
\text { class }\end{array}$} \\
\hline & Aspirin & $\begin{array}{l}\text { Indo- } \\
\text { methacin }\end{array}$ & Steroids & $\begin{array}{l}\text { Other } \\
\text { drugs* }\end{array}$ & & & \\
\hline 1 & + & - & + & - & $\mathbf{P}$ & Fatty liver, infection & Died \\
\hline 2 & + & + & + & - & $\mathbf{P}$ & $\begin{array}{l}\text { Granulomatous hepatitis, } \\
\text { cardiomyopathy, deforming arthritis }\end{array}$ & III \\
\hline 3 & + & + & - & - & $\mathbf{M}$ & Uveitis & I \\
\hline 4 & + & + & - & - & $\mathbf{M}$ & Deformities & II \\
\hline 5 & + & + & + & - & $\mathbf{P}$. & Amyloidosis, renal failure & Died \\
\hline 6 & + & - & - & - & $\mathbf{M}$ & Jaundice & II \\
\hline 7 & + & + & - & - & $\mathbf{M}$ & - & I \\
\hline 8 & + & + & + & - & $\mathbf{P}$ & Deforming arthritis & III \\
\hline 9 & + & + & - & - & $\mathbf{M}$ & - & I \\
\hline 10 & + & - & + & C & $\mathbf{P}$ & Vasculitis & II \\
\hline 11 & + & + & + & - & $\mathbf{M}$ & - & II \\
\hline 12 & + & - & - & - & $\mathbf{M}$ & - & I \\
\hline 13 & + & - & - & - & $\mathbf{M}$ & - & I \\
\hline 14 & + & + & + & MT & $\mathbf{P}$ & Deforming arthritis & III \\
\hline 15 & + & + & - & MT & $\mathbf{P}$ & Deforming arthritis & III \\
\hline 16 & + & + & + & - & $\mathbf{P}$ & Infection & Died \\
\hline 17 & + & + & - & - & $\mathbf{M}$ & & II \\
\hline 18 & + & + & - & - & $\mathbf{M}$ & Episcleritis & I \\
\hline
\end{tabular}


was found despite detailed investigation. Sarcoidosis was considered but she had a normal chest radiograph, negative Kveim test, and normal calcium status. We thus concluded that the granulomatous hepatitis was related to Still's disease. Later she developed heart failure which responded to digitalis, diuretics, and corticosteroids. The echocardiogram showed a large dilated heart with poor contractility which was suggestive of a congestive cardiomyopathy. She had been receiving corticosteroids for several years and has refused cyclophosphamide. All attempts to withdraw the steroids and to convert to an alternate day dosage have resulted in relapse. Another patient developed a transient hyperbilirubinaemia with concomitant increases in liver enzymes. This was probably an unrelated episode of viral hepatitis.

\section{OCULAR COMPLICATIONS}

A young male patient developed pauciarticular arthritis and chronic asymptomatic anterior uveitis. The test for antinuclear antibodies was negative. The systemic and the ocular inflammation subsided on treatment with aspirin and indomethacin and have not recurred within five years. Episcleritis was observed to parallel the course of fever and joint pain in a young female patient. She received topical betamethasone drops and responded. Her systemic disease and the scleral inflammation subsided with aspirin and indomethacin. No recurrence has been noted over the last 18 months.

\section{AMYLOIDOSIS}

This complication developed in a young female patient after polycyclic disease lasting eight years. She had developed advanced renal failure when she left hospital and there were no prospects of entering a dialysis programme.

\section{VASCULITIS}

Cutaneous vasculitis with a polycyclic course developed in a young male patient and manifested as palpable purpura. He received four pulses of cyclophosphamide injections at intervals of one month and responded well. Subsequently he was managed with aspirin and indomethacin. There has been no recurrence.

There were two deaths in hospital and another outside. The two hospital deaths were a result of nosocomial infection acquired during corticosteroid treatment. At necropsy, apart from the findings of infection, no characteristic lesions were observed.

Treatment varied before the prospective study started in 1983. Since then aspirin has been used initially (up to $4800 \mathrm{mg} /$ day) for two to three weeks. Indomethacin (up to $150 \mathrm{mg} / \mathrm{day}$ ) is added if there is no response and is continued for four to six weeks. During this time patients also receive paracetamol. If there is no response at the end of six to eight weeks, then corticosteroids are used. The complications are treated as required. Eight patients $(44 \%)$ required corticosteroids for control of their systemic disease and complications.

\section{Discussion}

Prolonged unexplained fever often necessitates a systematic review of the history, physical findings, and available laboratory data to formulate a plan of investigation. ${ }^{13}$ Developments in immunological methods and imaging techniques have expedited the early diagnosis of several diseases which caused diagnostic problems in the past. ${ }^{14}$ Nowhere has the effect of immunodiagnostics been felt more than in the management of patients with 'collagen diseases'. These diseases remain important causes of prolonged unexplained fever but the previously unassailable primacy of systemic lupus erythematosus has been challenged by adult onset Still's disease. ${ }^{13}$ This is a result of the ready availability of a confirmatory test for the former and the complete absence of any reproducible laboratory abnormality in the latter. The diagnosis of adult onset Still's disease is one of exclusion and many patients undergo several unnecessary procedures including laparotomy. 5811 This condition should be strongly suspected in relatively well preserved patients with a febrile illness lasting several months. The longer the duration, and the better the preservation, the more sure the clinical diagnosis. The preservation of these patients is in sharp contrast to febrile patients with tuberculosis, other infections, and lymphoreticular malignancies.

One of the major reasons for the infrequency of this diagnosis is the lack of awareness. Retrospectively analysing the data from Petersdorf and Beesons' classic paper on prolonged unexplained fever, ${ }^{14}$ Larson suggested that at least two of the seven undiagnosed patients had adult onset Still's disease. ${ }^{5}$ We believe that increased awareness will promote an early positive diagnosis and avoid expensive and dangerous investigations.

The clinical presentation of our patients was similar to that described earlier, but there were some important differences. The typical evanescent rash of Still's disease ${ }^{356}$ was difficult to observe owing to natural pigmentation. As the rash is an important diagnostic feature, ${ }^{57911}$ its absence makes the rest of the criteria for diagnosis non-specific. The careful observation of inpatients during the febrile episodes showed the typical behaviour of the rash in nine patients. Only four of these patients had been aware of a rash. The classically described double quotidian pattern of fever was observed in only four patients, but the evening spike of fever with rapid defervescence was observed in 13 patients. This led to confusion with tuberculosis, but the sharp increase and decrease of fever accompanied by the rash helped establish the diagnosis of adult onset Still's disease. ${ }^{5}$ Lymph node enlargement was observed in $67 \%$ of our patients but the enlargement was clinically important in only $11 \%$. This is different from the observations made in children ${ }^{15}{ }^{16}$ and adults ${ }^{7}$ with Still's disease where prominent lymphadenopathy often occurs. A few small nodes should not be used as a criterion for the diagnosis of adult onset Still's disease. ${ }^{7}$

The development of several life threatening complications in patients with adult onset Still's 
disease emphasises the need for an early diagnosis and intensive treatment. Severe destructive arthritis requiring joint replacement and treatment with disease modifying drugs has been recognised as a major problem in long term observations. ${ }^{7} 10$ Our experience was similar. Corticosteroids did not suppress the progressive articular destruction once it had set in. We have recently started to use methotrexate in two of these patients and the initial response is encouraging. This form of treatment could be used for patients with the prolonged febrile or the polycyclic form with the intention of preventing deformity and possibly amyloidosis. ${ }^{17}$ These two complications of childhood Still's disease are also a part of the adult disease and are causes of morbidity and mortality. ${ }^{16} 1819$

Liver dysfunction has often been observed but most patients have had asymptomatic increases in enzymes unaccompanied by clinical hepatic disease. ${ }^{57}$ In part this has been ascribed to treatment with aspirin. ${ }^{6}$ Serious hepatic failure $^{20}$ and chronic active hepatitis ${ }^{21}$ have been observed in a few instances. Our patient with granulomatous inflammation finally responsed to treatment with corticosteroids. Circumstantial evidence suggested that it was a manifestation of adult onset Still's disease.

Ocular complications have not been described previously, except for one patient with panophthalmitis ${ }^{22}$ and another with uveitis. ${ }^{11}$ Although eyesight was not affected by the inflammation in either of our patients, the need for an ophthalmic evaluation is obvious. We have not been able to find any previous reference to cutaneous vasculitis in adult onset Still's disease. This patient was investigated in detail for systemic lupus erythematosus, rheumatoid arthritis, hypocomplementaemia, Schönlein-Henoch purpura and infective endocarditis, but no other cause could be found. The vasculitis developed during an exacerbation of active systemic disease and responded to cyclophosphamide and prednisolone. We did not observe active myocarditis ${ }^{23}$ in any patient, though one patient had a dilated cardiomyopathy that could have started as a myocarditis. No abnormality in pulmonary function was observed in any of our patients, though this has been described elsewhere. ${ }^{24}$

As the clinical spectrum of this disease becomes known, many more complications will probably be recognised. The sharp distinction between the patients with a monocyclic course and those with a prolonged or polycyclic pattern was evident when the occurrence of complications was considered. Almost all the serious morbidity occurred in the latter group. Perhaps early treatment with immunosuppressive drugs may help to prevent some of these problems. ${ }^{725}$ The main need, however, is for a diagnostic test and a multicentre trial of disease modifying drugs.

1 Baum J, Baum E R. George Fredric Still and his account of childhood arthritis-a reappraisal. Am $\mathcal{7}$ Dis Child 1978; 132: 192-4.

2 Still G F. On a form of chronic joint disease in children. Med Chir Trans 1897; 80: 1-13; reprinted Am F Dis Child 1978; 132: 195-200.

3 Isdaile I C, Bywaters E G L. The rash in Still's disease. Q7 Med 1956; 25: 377-87.

4 Bywaters E G L. Still's disease in the adult. Ann Rheum Dis 1971; 30: 121-33.

5 Larson E B. Aduit Still's disease: evolution of a clinical syndrome and diagnosis, treatment and follow up of 17 patients. Medicine (Baltimore) 1984; 63: 82-91.

6 Esdaile J M, Tannenbaum H, Hawkins D. Adult Still's disease. Am F Med 1980; 68: 825-30.

7 Wouters J M G W, Van der Putte L B A. Adult onset Still's disease; clinical and laboratory features. Treatment and progress of 45 cases. Qf Med 1986; 61: 1055-65.

8 Kumar A, Bhat A, Bhadoria D P, Misra R, Malaviya A N. Adult Still's disease-a cause of pyrexia of unknown origin. $\mathcal{F}$ Assoc Physicians India 1986; 34: 270-2.

9 Aptekar R G, Decker J L, Bujak J S, Wolff S M. Adult onset juvenile rheumatoid arthritis. Arthriti Rheum 1973; 16: $715-8$

10 Elkon K B, Hughes G R V, Bywaters E G L, et al. Adult onset Still's disease: 20 years follow up. Arthritis Rheum 1982; 25: 647-54.

11 Medsger T A, Christy W C. Carpal arthritis and ankylosis in late onset Still's disease. Arthritis Rheum 1976; 19: 232-42.

12 Bambery P, Kaur U, Bhusnurmath S R, Gupta A, Deodhar $S \mathrm{D}$. Adult onset Still's disease in North India: a report on six patients. Rheumatol Int 1987; 7: 173-6.

13 Larson E B, Featherstone H J, Petersdorf R G. Fever of undetermined origin: diagnosis, treatment and follow up of 105 cases 1970-1980. Medicine (Baltimore) 1982; 61: 269-92.

14 Petersdorf R G, Beeson P B. Fever of unexplained origin report of 100 cases. Medicine (Baltimore) 1961; 40: 1-30

15 Schaller J, Wedgewood R J. Juvenile rheumatoid arthritis: a review. Pediatrics 1972; 50: 940-53.

16 Leak A M, Isenberg D A. Autoimmune rheumatic disorders in childhood-a comparison with adult onset disease. $Q \mathcal{J}$ Med 1989; 73: 875-94.

17 Dhillon V, Woo P, Isenberg D. Amyloidosis in the rheumatic diseases. Ann Rheum Dis 1989; 48: 696-701.

18 Allen R C, Ansell B M. Juvenile chronic arthritis-clinical subgroups with particular relationship to adult patterns of disease. Postgrad Med F 1986; 62: 821-6.

19 Harrington T H, Moran J J, Davis D E. Amyloidosis in adult onset Still's disease. F R heumatol 1981; 8: 833-6.

20 Baker D G, Schumacher H R, Reginato A J. Fifteen patients with adult onset Still's disease. Life threatening liver failure with adult onset Still's disease. Life threatening

21 Tesser J R P, Pisko E J, Hartz J W, Wienblatt M E. Chronic liver disease and adult Still's disease. Arthritis Rheum 1982 25: 579-83.

22 Bujak J S, Aptekar R G, Decker J L, Wolff S M. Juvenile rheumatoid arthritis presenting in the adult as fever of unknown origin. Medicine (Baltimore) 1973; 52: 431-44.

23 Bank I, Marboe C C, Redberg R F, Jacobs J. Myocarditis in adult Still's disease. Arthritis Rheum 1985; 28: 452-4.

24 Corbett A J, Zizic T M, Stevens M B. Adult onset Still's disease with an associated severe restrictive pulmonary defect: a case report. Ann Rheum Dis 1983; 42: 452-4.

25 Kaplinsky N, Pass M, Frankl O. An adult form of juvenile rheumatoid arthritis. Arch Intern Med 1980; 140: 1073-4. 